\title{
Influence of soil properties on yield and fruit maturity at harvest of 'Williams' pear
}

\author{
María Cristina Aruani ${ }^{1 *}$, Pablo Daniel Reeb ${ }^{1}$, and Norma Elizabeth Barnes ${ }^{1}$
}

In the Upper Rio Negro Valley, northern Patagonia (Argentina), there is a large variability of soils and the success of a fruit plantation depends mostly on soil characteristics. The main objective of this work was to determine the relationships between yield and fruit internal maturity at harvest of pear trees (Pyrus communis L.) grown in soils with different properties. The soil around each of 30 trees was morphologically characterized by measuring physical, physic-chemical, and chemical variables. At harvest time, total and commercial yields were measured, and maturity was determined by measuring flesh firmness, soluble solids, and titratable acidity. According to edaphic variables, soils were classified into five groups. Yields presented significant differences among such groups and growing seasons. The distribution of commercial sizes was similar in soils with fine texture, and high $\mathrm{K}$ content $\left(897\right.$ and $663 \mathrm{mg} \mathrm{kg}^{-1}$ ) and cation-exchange capacity. Smaller fruits predominated in soil groups with high salinity $\left(6.1 \mathrm{dS} \mathrm{m}^{-1}\right.$ in surface and $10.8 \mathrm{dS} \mathrm{m}^{-1}$ in subsurface horizons) and shallow depth. The soil group with the highest salinity presented fruits with $11 \%$ more titratable acidity compared to all other groups. The soil group with the smallest depth presented fruits with high levels of flesh firmness $\left(11.18 \mathrm{~kg} \mathrm{~cm} \mathrm{~cm}^{-2}\right)$ and soluble solids $(14.8 \%)$. The selected set of edaphic variables allowed us to differentiate groups of soils and analyze its influence in pear tree yield, commercial sizes, and fruit internal maturity.

Key words: Integrative multivariate analysis, internal maturity indices, Pyrus communis, soils, yield.

\section{INTRODUCTION}

Argentina has a wide variety of climate and soil conditions that allows cultivating species from temperate, subtropical, and tropical zones and producing important exports of apples (Malus domestica Borkh.), pears (Pyrus communis L.), and citrus. The country is segmented into eight fruit regions (Altube et al., 2007). The southern region is the most important in terms of pear and apple production, it corresponds to northern Patagonia and includes areas from the provinces of Neuquén and Río Negro. The Upper Río Negro Valley is a narrow area of 1-12 km width and $130 \mathrm{~km}$ long located in northern Patagonia that comprises alluvial valleys from lower Neuquén and Limay rivers, as well as from upper Negro river. The Upper Río Negro Valley presents a large variability of soils (Talledo Yovera and Pacheco, 1969). Generally, when deciding which fruit tree species to implant, the soil quality of the orchard is not taken into consideration; however, achieving a successful, or not, implantation mostly relies on soil physical, physic-

${ }^{1}$ Universidad Nacional del Comahue, Facultad de Ciencias Agrarias, Ruta 151 km 12,5, Casilla 85, Cinco Saltos (8303), Río Negro, Argentina. "Corresponding author (mcaruani@gmail.com).

Received: 18 February 2014.

Accepted: 2 August 2014.

doi:10.4067/S0718-58392014000400013 chemical, and chemical properties (Aruani and Behmer, 2004; Draghi et al., 2005). Important soil agronomic factors such as texture, clay mineral type, structure, soil moisture, soil acidity or alkalinity, effective soil depth, and salinity, directly influence the development of the root system and indirectly the crop productivity level (Bengough et al., 2011).

Flooding is the most popular irrigation system applied in Upper Rio Negro Valley. The low efficiency of such method (Aruani et al., 2007) raises groundwater levels and generates a gradual soil salinization. Salt toxicity is one of the most limiting edaphic factors for producing good quality fruit. Excessive amounts of salts have adverse effects on soil physical and chemical properties, microbial processes, and plant growth (Liang et al., 2005). High osmotic potential generated by salts creates disturbances in the water absorption mechanisms, photosynthesis, protein synthesis, as well as in nutritional balances that affect fruit growth (Khayyat et al., 2007; Ajeet and Ramasare, 2009). Aruani et al. (2011) found that a high exchangeable Na percentage (ESP 20\%) was negatively associated with pear yield, and if ESP decreased in $30 \%$ there was a significant improvement in yield, commercial size and internal quality of fruits. Similar results were obtained by Tejada et al. (2006) that utilized organic amendment as a strategy to reduce the saline effect in soils. Various studies of soil profile indicate that adequate 
K nutrition during the rapid growth phase ensures balance between acid and sugar content. As a consequence, fruits have a pleasant sweet taste and storage is prolonged (Hudina and Štampar, 2005; Sánchez, 2007). Fallahi et al. (2010) and Stino et al. (2011) noted that a good $\mathrm{K}^{+}$ content in soils is crucial to ensure fruit size increments. Analogous results were obtained by Noë et al. (1997) when studying the effect of $\mathrm{N}$ and $\mathrm{K}$ on the quality of apple fruits. The authors reported an increment in fruit firmness and soluble solids, and better storage conditions.

The influence of factors that affect the fruit size of pear 'Williams' as pollination, fruit thinning, and girdling has been evaluated under experimental conditions (Dussi et al., 2008; Dussi and Sugar, 2010; Gimenez et al., 2010); however, there is limited knowledge about the effect of soil properties on yield and fruit quality. In Upper Rio Negro Valley, Echenique et al. (2007) and Apcarian et al. (2006) described the relationship of yield of grapevine cultivars on soils with hardened layers, and Sánchez et al. (2007) found that cover crops did affect soil properties and apple yield. In such context, the objective of this paper was to determine relationships between soil physical, chemical, and physic-chemical properties, yields and fruit internal maturity at harvest of pear trees 'Williams' in the Upper Rio Negro Valley.

\section{MATERIAL AND METHODS}

\section{Study area}

The study was conducted during three growing seasons (2008-2009, 2009-2010, and 2010-2011) in three commercial orchards implanted with pear trees (Pyrus communis L.) 'Williams'. Orchards were owned by the same grower. The experimental unit consisted in a tree and its surrounding soil. We selected 30 trees between 15 and $17 \mathrm{yr}$ old, in three orchards located in the Upper Rio Negro Valley (38 $54^{\prime}-38^{\circ} 44^{\prime}$ S, 68 $02^{\circ}-68^{\circ} 08^{\prime}$ W). Trees were trained using a trellis system with a planting distance of $4 \times 2 \mathrm{~m}$ and were irrigated by flooding. Crop management at all sites was performed according to standard cultural practices in the region of study and directed in the same way by the same technician. In every growing season, we added $150 \mathrm{U} \mathrm{N}$ applying half the dose in spring-summer and half the dose in autumn, and $8 \mathrm{~kg}$ tree $^{-1}$ chicken manure $(3.0 \% \mathrm{~N}, 1.0 \% \mathrm{P}, 2.2 \% \mathrm{~K}, 45 \% \mathrm{C}$ and $\mathrm{C} / \mathrm{N}$ ratio $=15$ ) in winter. Herbicides were used to control weeds. Paraquat (276 $\mathrm{g}_{\text {ai }} \mathrm{L}^{-1}$ ) was applied once in spring at a dose of $3 \mathrm{~L} \mathrm{ha}^{-1}$ and glyphosate $\left(1.92 \mathrm{~g}^{\mathrm{ai} \mathrm{L}} \mathrm{L}^{-1}\right)$ was applied five times in summer at a dose of $4 \mathrm{~L} \mathrm{ha}^{-1}$.

The parent material of soils is alluvial with aridic moisture regimen and termic temperature regime, which reflect conditions of water deficit throughout the year (CIL, 1991). The annual average temperature of the warmest month (January) is $21.9{ }^{\circ} \mathrm{C}$ and of the coldest month (July) is $5.7{ }^{\circ} \mathrm{C}$. The annual average precipitation is $224 \mathrm{~mm}$ (data from weather station installed in the College of Agricultural Sciences, Universidad Nacional del Comahue, period 1972-2010).

\section{Soil determinations}

To study the soil profile, in late spring 2008, test pits were opened at $1 \mathrm{~m}$ from the trunk of each selected plant. Internal and external morphological features of each profile were described and soil taxonomy was classified according to Soil Survey Staff (2010) (Table 1). Samples were taken from surface $(0-20 \mathrm{~cm})$ and subsurface

Table 1. Morphological characteristics of soils.

\begin{tabular}{|c|c|c|c|c|c|c|c|c|c|c|c|c|}
\hline \multirow[b]{2}{*}{ Horizons } & \multirow[b]{2}{*}{$\begin{array}{c}\text { Depth } \\
\mathrm{cm}\end{array}$} & \multicolumn{2}{|c|}{ Color (Munsell) } & \multirow[b]{2}{*}{ Texture } & \multicolumn{3}{|c|}{ Structure } & \multirow[b]{2}{*}{$\begin{array}{c}\text { Coarse } \\
\text { fragments, } \%\end{array}$} & \multirow[b]{2}{*}{ Mottles } & \multicolumn{2}{|c|}{ Consistence } & \multirow[b]{2}{*}{ Carbonates } \\
\hline & & Dry & Wetter & & Type & Classes & Grade & & & $\begin{array}{c}\text { Slightly } \\
\text { dry and wetter }\end{array}$ & $\begin{array}{l}\text { Slightly wetter } \\
\text { and wet }\end{array}$ & \\
\hline \multicolumn{13}{|c|}{ Typic Aquicambids, fine-silty family } \\
\hline Ap & $0-20$ & $10 \mathrm{YR} 6 / 2$ & $10 Y R 3 / 3$ & $\mathrm{Fa}$ & B1 & $\mathrm{F}$ & Mod & - & - & $\mathrm{Fr}$ & LA, LP & MLC \\
\hline $\mathrm{Bw}$ & $20-40$ & 10YR 7/3 & $10 \mathrm{YR} 4 / 2$ & fal & B1 & Med & Mod & - & - & Fir & $\mathrm{A}, \mathrm{P}$ & $\mathrm{FC}$ \\
\hline $\mathrm{Ck} 1$ & $40-55$ & $10 Y R 6 / 3$ & $10 Y R$ 4/1 & fl & & Structureless & & - & - & $\mathrm{Fr}$ & $\mathrm{LA}, \mathrm{LP}$ & FC \\
\hline Ck2 & $55-100$ & $10 \mathrm{YR} 6 / 3$ & $10 \mathrm{YR} 4 / 2$ & $\mathrm{f}$ & & Structureless & & 20 & Commons & $\mathrm{Fr}$ & LA, LP & $\mathrm{FC}$ \\
\hline $2 \mathrm{Ck} 3$ & $100+$ & - & - & $\mathrm{f}$ & - & - & - & $70-80$ & - & - & - & - \\
\hline \multicolumn{13}{|c|}{ Oxyaquic Torrifluvents, coarse-loamy family } \\
\hline Ap & $0-20$ & $10 Y R 4 / 3$ & $10 Y R 3 / 2$ & $\mathrm{f}$ & $\mathrm{B} 1$ & F a Med & Mod & - & - & $\mathrm{Fr}$ & LA, LP & $\mathrm{LC}$ \\
\hline $\mathrm{AC}$ & $20-40$ & $10 \mathrm{YR} 5 / 2$ & $10 \mathrm{YR} 3 / 3$ & fl & $\mathrm{Bl}$ & F a Med & Mod & - & - & $\mathrm{Fr}$ & LA, LP & $\mathrm{LC}$ \\
\hline $\mathrm{C} 1$ & $40-75$ & $10 \mathrm{YR} 6 / 2$ & $10 Y R 3 / 3$ & $\mathrm{f}$ & & Structureless & - & - & Commons & $\mathrm{Fr}$ & LA, LP & $\mathrm{MC}$ \\
\hline $\mathrm{C} 2$ & $75-100+$ & 10YR $6 / 2$ & $10 Y R 3 / 3$ & $\mathrm{f}$ & & Structureless & - & - & Abundant & $\mathrm{Fr}$ & NA, NP & MLC \\
\hline \multicolumn{13}{|c|}{ Typic Torriorthents, sandy-skeletal family } \\
\hline Ap & $0-16$ & $10 \mathrm{YR} 5 / 2$ & $10 Y R 3 / 3$ & $\mathrm{f}$ & B1 & $\mathrm{F}$ & $\mathrm{D}$ & 5 & - & $\mathrm{Fr}$ & LA, NP & - \\
\hline $\mathrm{C} 1$ & $16-32$ & $10 Y R 5 / 2$ & $10 Y R 3 / 3$ & fA & & Structureless & & 30 & - & $\mathrm{Fr}$ & $\mathrm{NA}, \mathrm{NP}$ & - \\
\hline $2 \mathrm{C} 2$ & $32-50$ & $10 \mathrm{YR} 6 / 2$ & $10 Y R 4 / 3$ & $\mathrm{~A}$ & & Structureless & & 70 & - & $\mathrm{Fr}$ & $\mathrm{NA}, \mathrm{NP}$ & - \\
\hline $3 \mathrm{C} 3$ & $50+$ & - & - & A & & Structureless & & $80-90$ & - & - & NA, NP & - \\
\hline \multicolumn{13}{|c|}{ Typic Fluvaquents, coarse-silty family } \\
\hline Ap & $0-20$ & $10 \mathrm{YR} 5 / 2$ & 10 YR $3 / 2$ & $\mathrm{fl}$ & $\mathrm{B} 1$ & $\mathrm{~F}$ & Mod & - & - & $\mathrm{Fr}$ & LA, LP & $\mathrm{LC}$ \\
\hline $\mathrm{C} 1$ & $20-40$ & $10 \mathrm{YR} 6 / 2$ & $10 \mathrm{YR} 4 / 2$ & $\mathrm{fl}$ & & Structureless & & - & - & Fir & LA, LP & $\mathrm{FC}$ \\
\hline $\mathrm{C} 2$ & $40-50$ & $10 \mathrm{YR} 6 / 2$ & $10 \mathrm{YR} 4 / 2$ & fl & & Structureless & & - & Commons & $\mathrm{Fr}$ & LA, LP & FC \\
\hline $\mathrm{C} 3$ & $50-78$ & $10 Y R \quad 6 / 2$ & $10 \mathrm{YR} 3 / 2$ & $\mathrm{fl}$ & & Structureless & & - & Abundant & $\mathrm{Fr}$ & LA, LP & FC \\
\hline
\end{tabular}

Texture: fa: clay loam; fal: silty clay loam; fl: silty loam; f: loam; fA: sandy loam; A: sandy; Structure: Type: Bl blocky; Classes: F: fine; Med: medium; Grade: Mod: moderate; D: slight; Consistence: Fr: friable; Fir: firm; LA: slightly sticky; LP: slightly plastic; P: plastic; Carbonate: MLC: very lightly carbonated; FC: strongly carbonated; LC: lightly carbonated; MC: moderately carbonated. 
horizons $(20-40 \mathrm{~cm})$ to determine: percentage of sand, silt and clay (hydrometer Bouyoucos method), $\mathrm{pH}$ measured in the saturation extract (pontentiometric method, portable $\mathrm{pH} / \mathrm{mV} /{ }^{\circ} \mathrm{C}$ Meter HI 8424 , Hanna Instruments, Woonsocket, Rhode Island, USA), electrical conductivity (EC dS m ${ }^{-1}$, Metrohm AG, Herisau, Switzerland), cations and anions measured in saturation extract, $\mathrm{Na}$ adsorption ratio (SAR), organic matter (OM) of the surface horizon (Walkley and Black, 1934), cation-exchange capacity (CEC), and exchangeable cations ( $\mathrm{K}$ and $\mathrm{Na})\left(\mathrm{NH}_{4}\right.$ acetate method, Flame Photometer 315, Metrolab, Buenos Aires, Argentina). In late spring 2009 and late spring 2010, soil samples were collected at the same sites and horizons to register the evolution of the following variables: $\mathrm{pH}, \mathrm{EC}$, soluble cations and anions, SAR, K and Na exchangeable cations, and OM from the surface horizon.

\section{Yield and internal maturity indices}

All the fruits from each tree were harvested ( 7 and 9 January 2009, 18 and 19 January 2010, and 10 and 11 January 2011) according to the official harvest authorization date for 'Williams' published by the National Secretary of Agriculture. Each fruit was individually weighed, and total yield was obtained by adding weights of all fruits for each tree, while commercial yield included only the sum of fruits $\geq 121 \mathrm{~g}$. Commercial yield to total yield ratio was calculated. We determined the trunk cross-sectional area (TCSA) of each tree and expressed total and commercial yield in $\mathrm{kg} \mathrm{cm}^{-2}$ TCSA. Fruits were classified according to standard commercial sizes: $60,70,80,90,100,110$, $120,135,150,165$, and 180 . These values indicate number of fruits per $18.2 \mathrm{~kg}$ box (Bramardi et al., 2006). In 2008-2009 and 2009-2010 seasons, 20 fruits from each tree were sampled to determine the following internal maturity indices: flesh firmness using an Effe-Gi-type manual penetrometer with an $8 \mathrm{~mm}$ plunger (FT 327, Facchini Srl, Alfonsine, Italy) and expressed in $\mathrm{kg} \mathrm{cm}^{-2}$; soluble solids (SS), measured with a refractometer (N1 Brix 0-32\%, Atago, Tokio, Japan) and expressed as \% SS; and total titratable acidity measured with a digital $\mathrm{pH}$ meter Atago-type neutralizing with $\mathrm{KOH}$ up to $\mathrm{pH}=8.1$ and expressed in $\mathrm{g} \%$ malic acid.

\section{Statistical analysis}

Variables were grouped in three sets according to each of the three aspects that they described (soil, yield, or maturity) and each set was submitted to the following analysis procedure. First, we analyzed linear relationships among all the variables using a scatterplot matrix and calculating Pearson correlation coefficients with Infostat program (Di Rienzo et al., 2011). To diminished colinearity among variables, we eliminated those variables that had a linear correlation coefficient greater than 0.85 . Secondly, with the remaining variables we ran a multiple factor analysis (MFA) as defined in Escofier and Pagés (1994), with three ways of multivariate analysis being: sites, variables, and growing seasons. This type of analysis allowed us to obtain consensus configuration of sites, to establish relationships among variables, and to analyze the evolution in time.

The above procedure was firstly applied to the set of soil variables and a classification of sites into groups according to their distance in the main plane was obtained. Subsequently, such groups were used as a classification variable to analyze differences in yield and maturity variables among the groups. In all analyses, 95\% confidence ellipses for each group mean were constructed. Multiple factor analysis (MFA) was executed with FactoMineR v.1.14 package (Husson et al., 2010) in R 2.14.0 (R Development Core Team, 2012). Groups were compared using ANOVA and multiple mean comparisons adjusted by Tukey test $(\mathrm{P}<0.05)$ for unbalanced data.

\section{RESULTS}

\section{Soil properties}

The first two dimensions of MFA accounts for $60 \%$ of the total variability (inertia). The complete description of the first two dimensions is presented in Table 2. Variables that consistently participated in the construction of dimension 1 over the $3 \mathrm{yr}$, included sand, silt, EC, \% calcium carbonate, and CEC all from the surface horizon; and $\mathrm{pH}, \mathrm{EC}, \mathrm{SAR}$, and \% calcium carbonate, all from the subsurface horizon. Dimension 2 is highly correlated with $\mathrm{K}$ and CEC of the subsurface horizon in all $3 \mathrm{yr}$.

The configuration of sites in the principal plane of the MFA is presented in Figure 1a. Sites were divided into five soil groups according to Euclidean distances.

Table 2. Correlation coefficients between principal dimensions and edaphic variables for each growing season.

\begin{tabular}{|c|c|c|c|c|c|c|}
\hline \multirow[b]{2}{*}{ Edaphic variables } & \multicolumn{2}{|c|}{ 2008-2009 } & \multicolumn{2}{|c|}{$2009-2010$} & \multicolumn{2}{|c|}{ 2010-2011 } \\
\hline & Dim1 & $\operatorname{Dim} 2$ & Dim1 & $\operatorname{Dim} 2$ & Dim1 & Dim2 \\
\hline \multicolumn{7}{|l|}{ Surface horizon } \\
\hline $\mathrm{OM}$ & 0.47 & -0.15 & 0.48 & -0.35 & 0.34 & -0.16 \\
\hline Sand & -0.90 & -0.21 & -0.80 & -0.44 & -0.87 & -0.30 \\
\hline Silt & 0.85 & -0.04 & 0.81 & 0.19 & 0.84 & 0.10 \\
\hline Clay & 0.72 & 0.54 & 0.55 & 0.70 & 0.68 & 0.49 \\
\hline $\mathrm{pH}$ & 0.57 & -0.12 & 0.81 & -0.08 & 0.47 & 0.02 \\
\hline $\mathrm{EC}$ & 0.78 & -0.40 & 0.85 & -0.28 & 0.73 & -0.47 \\
\hline $\mathrm{K}^{+}$ & 0.70 & 0.56 & 0.58 & -0.22 & 0.34 & 0.73 \\
\hline $\mathrm{CO}_{3} \mathrm{Ca}$ & 0.76 & -0.26 & 0.85 & -0.21 & 0.81 & -0.19 \\
\hline Bulk density & -0.15 & 0.53 & -0.61 & 0.43 & -0.51 & 0.63 \\
\hline CEC & 0.70 & 0.30 & 0.63 & 0.45 & 0.71 & 0.23 \\
\hline \multicolumn{7}{|l|}{ Subsurface horizon } \\
\hline Silt & 0.70 & -0.03 & 0.68 & 0.15 & 0.68 & 0.05 \\
\hline Clay & 0.55 & 0.45 & 0.44 & 0.59 & 0.55 & 0.41 \\
\hline $\mathrm{pH}$ & 0.69 & -0.05 & 0.87 & -0.12 & 0.71 & 0.08 \\
\hline EC & 0.77 & -0.55 & 0.90 & -0.21 & 0.81 & -0.47 \\
\hline $\mathrm{K}^{+}$ & 0.41 & 0.65 & 0.06 & 0.84 & -0.01 & 0.76 \\
\hline SAR & 0.70 & -0.55 & 0.86 & -0.26 & 0.75 & -0.53 \\
\hline $\mathrm{CO}_{3} \mathrm{Ca}$ & 0.67 & -0.16 & 0.71 & 0.05 & 0.68 & -0.13 \\
\hline Bulk density & -0.21 & 0.14 & -0.24 & 0.14 & 0.68 & 0.41 \\
\hline CEC & 0.11 & 0.76 & -0.11 & 0.85 & 0.08 & 0.71 \\
\hline
\end{tabular}

OM: organic matter; EC: electrical conductivity; K: exchangeable K; SAR: $\mathrm{Na}$ adsorption ratio; CEC: cation-exchange capacity. 

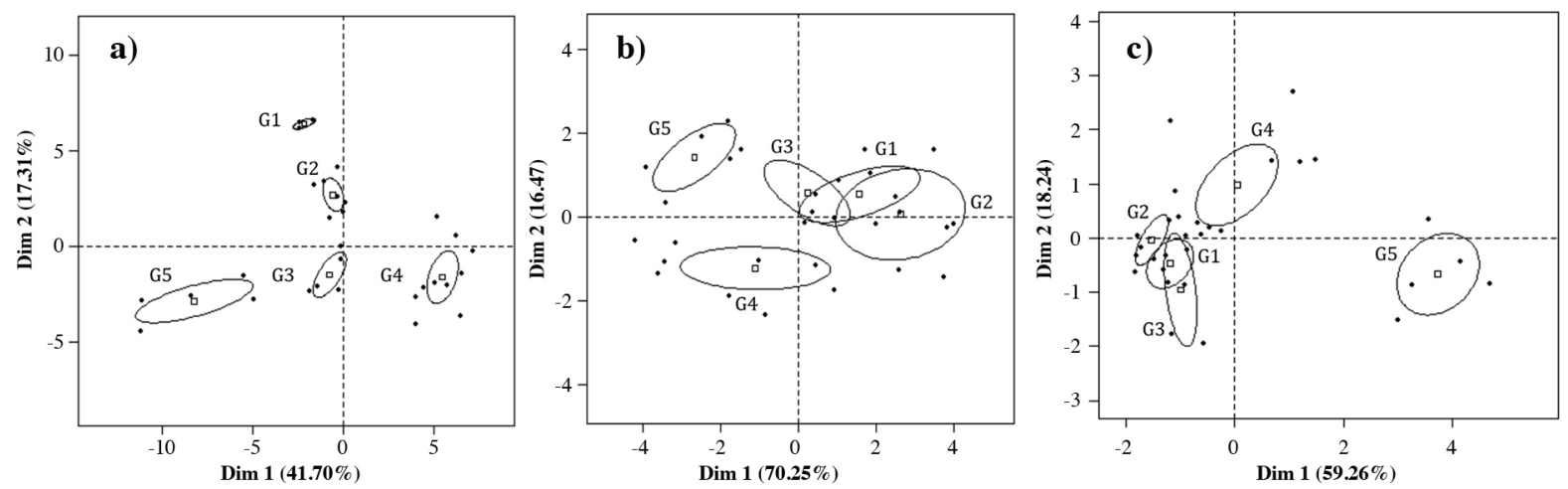

$\bullet=$ sites, $\square=$ group mean, $\longrightarrow=95 \%$ confidence ellipse of group mean.

Figure 1. Consensus configuration of experimental sites according to factorial multiple analysis considering (a) edaphic, (b) yield, and (c) fruit maturity variables. (a) and (b) are based on three growing seasons (2008-2009, 2009-2010, and 2010-2011) while (c) is based on two growing seasons (2008-2009 and 2009-2010).

\section{Yield}

Dimension 1 and dimension 2 of the MFA explained $86.9 \%$ of the total inertia. Correlations between yield variables and dimensions are presented in Table 3 . The configuration of sites in the principal plane of the MFA is presented in Figure 1b. Group labels correspond to soil groups identified in the MFA of soil properties. There is an overlapping of means from groups 1,2, and 3 while group 4 and 5 differ from each other as well as with other groups. The ANOVA results for two response variables, total yield and commercial yield, reported differences for the main effects of growing season $(P=0.002$ for total yields and $\mathrm{P}=0.0002$ for commercial yield) and soil groups $(\mathrm{P}<0.0000$ for total yield and $\mathrm{P}<0.0000$ for commercial yield), and no interaction between them. Considering the growing season effect, we found that total yield was higher in the first and third season, and commercial yield was lower in the second season (Figure 2). Yield was also different among soil groups (Table 4). Total yield was higher in soil groups 1 and 2, intermediate in groups 3 and 4, and lower in group 5 . Commercial yield was also higher in soil groups 1 and 2 , but intermediate values were found only in group 3, and the lowest values were obtained in groups 4 and 5 . When fruits were classified according to commercial size and soil group (Figure 3a), we observed a similar fruit size distribution in group 1 and 2. Groups 4 and 5 were characterized by a higher percentage of small fruits (size 180). If we compare across growing seasons (Figure $3 b$ ), we can see that in 2009-2010 we obtained higher percentage of small fruits (size 180).

Table 3. Correlation coefficients between principal dimensions and yield variables for each growing season.

\begin{tabular}{|c|c|c|c|c|c|c|}
\hline \multirow[b]{2}{*}{ Variable } & \multicolumn{2}{|c|}{$2008-2009$} & \multicolumn{2}{|c|}{$2009-2010$} & \multicolumn{2}{|c|}{ 2010-2011 } \\
\hline & Dim1 & $\operatorname{Dim} 2$ & Dim1 & Dim2 & Dim1 & Dim2 \\
\hline Total yield, $\mathrm{kg} \mathrm{pl}^{-1}$ & 0.87 & -0.51 & 0.74 & 0.66 & 0.91 & -0.38 \\
\hline Commercial yield, $\mathrm{kg} \mathrm{pl}^{-1}$ & 0.99 & -0.04 & 0.99 & -0.04 & 0.98 & -0.14 \\
\hline Commercial yield, $\%$ & 0.78 & 0.62 & 0.76 & -0.64 & 0.76 & 0.65 \\
\hline
\end{tabular}

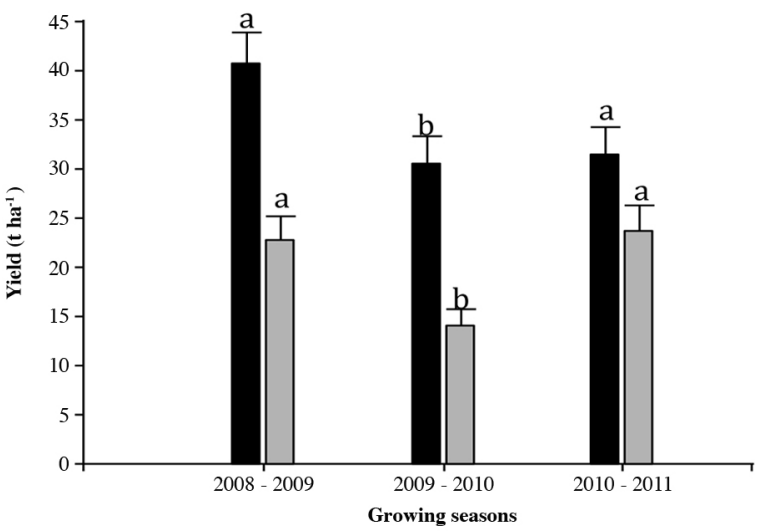

Different letters on bars corresponding to the same response variable, total yield (black) or commercial yield (grey) indicate significant differences between growing seasons according to Tukey test $(\mathrm{P}<0.05)$.

Figure 2. Total and commercial yields for growing season. Vertical bars correspond to standard error. Growing seasons $n=30$.

\section{Internal maturity indices}

The configuration of sites in the principal plane of the MFA is presented in Figure 1c. Group labels correspond to the soil groups identified in the MFA of soil properties. The first two dimensions accounted for $78 \%$ of the total inertia. Soil groups 4 and 5 presented larger variability and soil groups 3 and 1 overlapped. Correlations between quality variables and dimensions are presented in Table 5 .

Table 4. Means of yield variables by soil groups based on three growing seasons: 2008-2009, 2009-2010, and 2010-2011.

\begin{tabular}{|c|c|c|c|c|c|}
\hline \multirow[b]{2}{*}{ Variable } & \multicolumn{5}{|c|}{ Soils groups } \\
\hline & $\mathrm{G} 1(3)^{\mathrm{a}}$ & G2 (7) & G3 (5) & G4 (10) & G5 (5) \\
\hline Total yield, $\mathrm{kg} \mathrm{cm}^{-2}$ per TCSA & $0.034 \mathrm{a}$ & $0.034 \mathrm{a}$ & $0.029 \mathrm{~b}$ & $0.026 \mathrm{~b}$ & $0.009 \mathrm{c}$ \\
\hline $\begin{array}{l}\text { Commercial yield, } \mathrm{kg} \mathrm{cm}^{-2} \\
\text { per TCSA }\end{array}$ & $0.023 \mathrm{a}$ & $0.023 a$ & $0.015 b$ & $0.001 \mathrm{c}$ & $0.005 \mathrm{c}$ \\
\hline Commercial/total yield, $\%$ & $70.0 \mathrm{a}$ & $70.0 \mathrm{a}$ & $62.0 \mathrm{~b}$ & $40.0 \mathrm{c}$ & $55.0 \mathrm{c}$ \\
\hline Total yield, $\mathrm{t} \mathrm{ha}^{-1(\mathrm{~b})}$ & $39.5 \mathrm{a}$ & $47.1 \mathrm{a}$ & $33.6 b$ & $35.5 b$ & $12.0 \mathrm{c}$ \\
\hline Commercial yield, $\mathrm{t} \mathrm{ha}^{-1}$ & $28.6 \mathrm{a}$ & $33.2 \mathrm{a}$ & $20.3 b$ & $15.1 \mathrm{c}$ & $7.3 \mathrm{c}$ \\
\hline
\end{tabular}

anumber of sites.

${ }^{\text {b}}$ Total yield corresponds to a density of 1250 plants ha ${ }^{-1}$

Different letters in each row indicate significant differences between soil groups according to Tukey test $(\mathrm{P}<0.05)$.

TCSA: trunk cross-sectional area. 

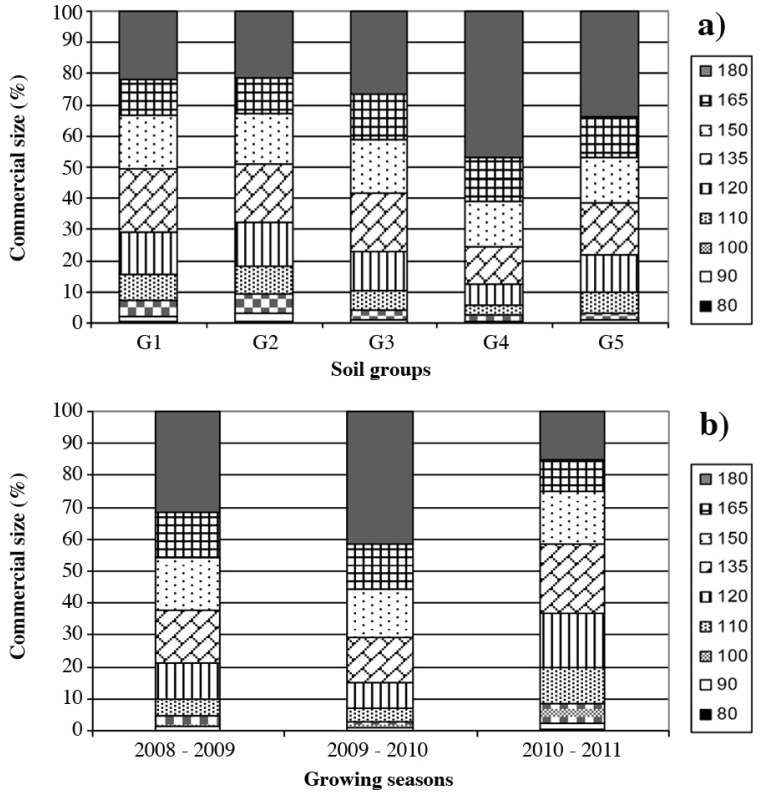

Figure 3. Commercial fruit size in number of fruits over total by soil groups (a) and growing season (b). Fruit size indicates number of fruits per $18.2 \mathrm{~kg}$ box.

Flesh firmness and titratable acidity presented significant interaction effect between soil group and growing season $(\mathrm{P}=0.01$ and $\mathrm{P}=0.004$, respectively) (Table 6). Soluble solids presented only significant effect of soil group $(\mathrm{P}=0.00001)$ with groups 1 to 4 being significantly lower (11\%) compared to group 5 (14\%).

Table 5. Correlation coefficients between principal dimensions and internal maturity indices variables for growing seasons 2008-2009 and 2009-2010.

\begin{tabular}{lccccc}
\hline & \multicolumn{2}{c}{$2008-2009$} & & \multicolumn{2}{c}{$2009-2010$} \\
\cline { 2 - 3 } \cline { 6 - 7 } Variable & Dim1 & Dim2 & & Dim1 & Dim2 \\
\hline Flesh firmness & 0.87 & -0.41 & & 0.86 & 0.40 \\
Soluble solids & 0.95 & 0.03 & & 0.91 & 0.17 \\
Titratable acidity & 0.36 & 0.92 & & -0.70 & 0.70 \\
\hline
\end{tabular}

\section{DISCUSSION}

\section{Characterization of soil groups}

Taxonomically, soils pertained to order Aridisols, suborder Cambids, and order Entisols, suborders Orthents and Fluvents. The predominance of the aquic subgroup in both orders indicated drainage problems with different degrees of hydromorphism. Table 7 shows means of edaphic variables for each group.
Table 7. Means of edaphic variables by soil groups based on three growing seasons: 2008-2009, 2009-2010, and 2010-2011.

\begin{tabular}{|c|c|c|c|c|c|}
\hline \multirow[b]{3}{*}{ Edaphic variable } & \multicolumn{5}{|c|}{ Soils groups } \\
\hline & G1 (3) ${ }^{\mathrm{a}}$ & G2 (7) & G3 (5) & G4 (10) & G5 (5) \\
\hline & \multicolumn{5}{|c|}{ Surface horizon } \\
\hline $\mathrm{OM}, \mathrm{g} \mathrm{kg}^{-1}$ & $30.5 \mathrm{~b}$ & $30.6 \mathrm{~b}$ & $29.5 \mathrm{~b}$ & $39.2 \mathrm{a}$ & $34.1 \mathrm{ab}$ \\
\hline Sands, $\%$ & $25.9 \mathrm{c}$ & $31.8 \mathrm{~b}$ & $34.9 \mathrm{~b}$ & $23.2 \mathrm{c}$ & $57.2 \mathrm{a}$ \\
\hline Silt, \% & $43.7 \mathrm{ab}$ & $40.8 \mathrm{~b}$ & $45.7 \mathrm{ab}$ & $49.8 \mathrm{a}$ & $27.7 \mathrm{c}$ \\
\hline Clay, \% & $30.4 \mathrm{a}$ & $27.4 \mathrm{c}$ & $19.4 \mathrm{~b}$ & $27.3 \mathrm{c}$ & $15.1 \mathrm{~d}$ \\
\hline $\mathrm{pH}$ & $7.29 \mathrm{a}$ & $7.42 \mathrm{a}$ & $7.71 \mathrm{~b}$ & $7.68 \mathrm{~b}$ & $7.02 \mathrm{c}$ \\
\hline $\mathrm{EC}, \mathrm{dS} \mathrm{m}^{-1}$ & $1.1 \mathrm{bd}$ & $2.0 \mathrm{bd}$ & $3.7 \mathrm{c}$ & $6.1 \mathrm{a}$ & $0.7 \mathrm{~d}$ \\
\hline $\mathrm{K}^{+}, \mathrm{mg} \mathrm{kg}^{-1}$ & $897.0 \mathrm{a}$ & $585.0 \mathrm{~b}$ & $663.0 \mathrm{~b}$ & $585.0 \mathrm{~b}$ & $312.0 \mathrm{c}$ \\
\hline $\mathrm{CaCO}_{3}, \%$ & $2.7 \mathrm{bd}$ & $3.5 \mathrm{~b}$ & $5.0 \mathrm{c}$ & $6.0 \mathrm{a}$ & $1.7 \mathrm{~d}$ \\
\hline Bulk density, $\mathrm{t} \mathrm{m}^{-3}$ & $1.23 \mathrm{a}$ & $1.13 \mathrm{a}$ & $1.13 \mathrm{a}$ & $0.88 \mathrm{~b}$ & $0.98 \mathrm{~b}$ \\
\hline \multirow[t]{2}{*}{$\mathrm{CEC}, \mathrm{cmol}_{+} \mathrm{kg}^{-1}$} & $32.4 \mathrm{a}$ & $32.0 \mathrm{a}$ & $27.5 \mathrm{~b}$ & $33.5 \mathrm{a}$ & $26.1 \mathrm{~b}$ \\
\hline & \multicolumn{5}{|c|}{ Subsurface horizon } \\
\hline Silt, $\%$ & $49.4 \mathrm{a}$ & $50.6 \mathrm{a}$ & $56.4 \mathrm{a}$ & $59.5 \mathrm{a}$ & $29.4 b$ \\
\hline Clay, \% & $21.5 \mathrm{a}$ & $23.8 \mathrm{a}$ & $16.5 \mathrm{~b}$ & $22.7 \mathrm{a}$ & $12.1 \mathrm{~b}$ \\
\hline $\mathrm{pH}$ & $7.3 b$ & $7.59 b$ & $7.6 \mathrm{~b}$ & $7.8 \mathrm{a}$ & $6.8 \mathrm{c}$ \\
\hline $\mathrm{EC}, \mathrm{dS} \mathrm{m}^{-1}$ & $1.7 \mathrm{c}$ & $4.6 \mathrm{~b}$ & $5.2 \mathrm{~b}$ & $10.8 \mathrm{a}$ & $0.4 \mathrm{c}$ \\
\hline $\mathrm{K}^{+}, \mathrm{mg} \mathrm{kg}^{-1}$ & $819.0 \mathrm{a}$ & $468.0 \mathrm{~b}$ & $382.0 \mathrm{bc}$ & $390.0 \mathrm{bc}$ & $234.0 \mathrm{c}$ \\
\hline SAR & $1.6 \mathrm{~b}$ & $8.34 \mathrm{c}$ & $7.24 \mathrm{c}$ & $18.0 \mathrm{a}$ & $1.2 \mathrm{~b}$ \\
\hline $\mathrm{CaCO}_{3}, \%$ & $3.3 \mathrm{~b}$ & $5.5 \mathrm{c}$ & $5.5 \mathrm{ca}$ & $6.9 \mathrm{a}$ & $2.5 \mathrm{~b}$ \\
\hline Bulk density, $\mathrm{t} \mathrm{m}^{-3}$ & 1.28 & 1.26 & 1.34 & 1.24 & - \\
\hline $\mathrm{CEC}, \mathrm{cmol}_{+} \mathrm{kg}^{-1}$ & $30.6 \mathrm{a}$ & $30.1 \mathrm{a}$ & $25.2 b$ & $25.9 \mathrm{~b}$ & $24.4 \mathrm{~b}$ \\
\hline
\end{tabular}

${ }^{\mathrm{a}}$ Number of sites.

OM: organic matter; EC: electrical conductivity; K: exchangeable K; SAR: $\mathrm{Na}$ adsorption ratio; CEC: cation-exchange capacity.

Different letters in each row indicate significant differences between soil groups according to Tukey test $(\mathrm{P}<0.05)$.

Group 1 included $10 \%$ of sites. Soils corresponded to order Aridisols classified as Typic Aquicambids, finesilty family, they were deep soils that had predominantly loamy clay texture on the surface and loamy-loamy silty texture in the subsurface. They were free of salts and had a neutral $\mathrm{pH}$ with a high level or organic matter (30.5 $\mathrm{g} \mathrm{kg}^{-1}$ ) for the Upper Rio Negro Valley area (Aruani et al., 2001). Both horizons were very well supplied with $\mathrm{K}$ (897-819 $\mathrm{mg} \mathrm{kg}^{-1}$ ). The calcium carbonate content indicated slightly calcareous soils (FAO, 2009).

Group 2 included 23\% of sites. They corresponded to the same soil and texture classification of group 1 in both horizons. These were deep soils, slightly saline in the subsurface layer, and with a slightly alkaline $\mathrm{pH}$ (Soil Survey Manual, 1995). Group 1 and group 2 presented higher percentages of clay and CEC levels than other groups. Soils were well supplied with organic matter but contain $35 \%$ less $\mathrm{K}$ than group 1 . The percentage of calcium carbonate was moderate $(3.5 \%$ to $5.5 \%)$ (FAO, 2009). In groups 1 and 2, height of water table was below $100 \mathrm{~cm}$ in winter and remained between 80 and $90 \mathrm{~cm}$ during the vegetative period; however, scare reddish spots were observed in the profile below $50 \mathrm{~cm}$ depth due to

Table 6. Means of flesh firmness and titratable acidity by soil groups and growing season.

\begin{tabular}{|c|c|c|c|c|c|c|c|c|c|c|}
\hline \multirow[b]{2}{*}{ Variable } & \multicolumn{5}{|c|}{$2008-2009$} & \multicolumn{5}{|c|}{$2010-2011$} \\
\hline & G1 & $\mathrm{G} 2$ & G3 & G4 & G5 & G1 & $\mathrm{G} 2$ & G3 & G4 & G5 \\
\hline Flesh firmness, $\mathrm{kg} \mathrm{cm}^{-2}$ & $9.42 \mathrm{ab}$ & $8.96 \mathrm{a}$ & $10.36 \mathrm{bc}$ & $9.53 \mathrm{ab}$ & $11.42 \mathrm{c}$ & $9.55 \mathrm{ab}$ & $9.27 \mathrm{ab}$ & $9.37 \mathrm{ab}$ & $9.86 \mathrm{ab}$ & $10.97 \mathrm{c}$ \\
\hline Titratable acidity, g \% malic acid & $0.543 \mathrm{ab}$ & $0.580 \mathrm{ab}$ & $0.510 \mathrm{a}$ & $0.712 \mathrm{c}$ & $0.613 \mathrm{ab}$ & $0.629 \mathrm{ab}$ & $0.649 \mathrm{bc}$ & $0.663 \mathrm{bc}$ & $0.607 \mathrm{ab}$ & $0.549 \mathrm{ab}$ \\
\hline
\end{tabular}

Different letters in each row indicate significant differences between groups of soils and growing seasons according to Tukey test $(\mathrm{P}<0.05)$. 
fluctuations in the capillary flow during the irrigation season.

Group 3 comprised $16 \%$ of sites. Soils corresponded to order Entisols classified as Oxyaquic Torrifluvents, coarseloamy family. These were deep soils with predominant loamy textures in both horizons, with a slightly alkaline $\mathrm{pH}$ and slightly saline content in both horizons. Soils were well supplied with organic matter, and K content ranged from 382-663 $\mathrm{mg} \mathrm{kg}^{-1}$ (Table 7). The percentage of calcium carbonate was moderate (FAO, 2009). As well as in groups 1 and 2, we observed capillary flow fluctuations below $50 \mathrm{~cm}$ of depth caused by the irrigation system. The water table remained between 80 and $90 \mathrm{~cm}$, during the vegetative period.

Group 4 comprised $33 \%$ of sites. Soils were classified as Typic Fluvaquents, coarse-silty family. These were moderately deep soils that were limited by the presence of the water table at $70 \mathrm{~cm}$ depth during the vegetative period but such level fell below $100 \mathrm{~cm}$ in winter. These soils were homogeneous and had a silty loamy texture throughout the profile. They differed from the above

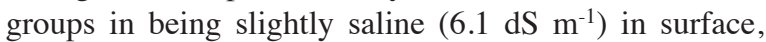
and moderately saline $\left(10.8 \mathrm{dS} \mathrm{m}^{-1}\right)$, sodic (RAS 18) with a high $34 \%$ of ESP in the subsurface horizon. The $\mathrm{pH}$ was slightly alkaline. This group had the highest content of $\mathrm{OM}$, and $\mathrm{K}$ content similar to group 3. According to Grattan and Grieve (1998), soils with a good nutritional status can counteract the negative impact of salts on fruit production. Soils in group 4 had a high calcium carbonate percentage (6.0-6.9\%) (FAO, 2009), and marked hydromorphic symptoms below $40 \mathrm{~cm}$.

Group 5 consisted of $16 \%$ of all sampled sites. Soils were classified as Entisols, order Typics Torriorthents, sandy-skeletal family, and subsoil with high content of coarse elements $(80 \%)$. These soils were moderately deep $(50 \mathrm{~cm})$ with two sites being shallow $(30 \mathrm{~cm})$. They contained a high percentage of sand, thus being somewhat excessively drained. They were well supplied with OM, contained lower concentrations of $\mathrm{K}$ compared to other groups, and had a neutral $\mathrm{pH}$. They were non saline soils with low bulk density, and low percentage of calcium carbonate $(1.7 \%-2.5 \%)$.

\section{Relationships between soil characteristics and tree yield}

Fruit growth is largely conditioned by internal (plant), and external (management and environmental) factors. With regard to external conditions, Sharples, (1980) showed that physical and chemical properties of soils and climatic factors affect the rate of ripening and cooking qualities of pears grown in South Africa, North America, and southeastern England. Stino et al. (2011) determined that one of the soil variables that directly influence the fruit growth phase is $\mathrm{K}^{+}$, which serves to maintain the fundamental condition of turgidity of cells. A good $\mathrm{K}^{+}$ nutrition in the fruit is associated with good equilibrium between acids and sugars content, good ripening, and good eating quality (Marcelle, 1995). Fallahi et al. (2010) determined that $\mathrm{K}$ fertilization increased fruit size, yield, and acidity in four apple cultivars. In this research, foliar analysis of the selected plants (data not shown) reported $\mathrm{K}$ levels between $1.5 \%-1.7 \%$, such levels are considered normal for pear 'Williams' (Sánchez, 2007).

Soil groups 1 and 2 had higher commercial yields (70\%) (Table 4) and were associated with soils that had higher $\mathrm{K}^{+}$content, $\mathrm{CEC}$, and percentage of clay in both horizons as well as lower saline levels, all these variables have a positive effect in fruit size (Merwin and Warren, 1994).

Soils in group 3 had lower level of commercial production $(62 \%)$ than those in groups 1 and 2 . Soils in group 3 presented the highest percentage of sand, lower CEC, $50 \%$ more salt in the surface horizon and $12 \%$ in the sub-surface horizon, and lower content of $\mathrm{K}^{+}$. Bronwyn et al. (1995) obtained a $30 \%$ reduction in yield of pear trees 'Williams' and a higher proportion of small fruits, in soils with similar salt concentration to soils studied in group 3 .

In group 4 the high salt effect and high prevalence of $\mathrm{Na}$ mainly in the second horizon, negatively affected the commercial production (Aruani et al., 2011). Although groups 4 and 3 had similar total production, only $40 \%$ was commercial yield in group 4 (Table 4). Analogous situation were recorded by Grattan and Grieve (1998) and Khayyat et al. (2007). In saline soils, Rhoades et al. (1992) stated that yield losses start with EC values greater than $2 \mathrm{dS} \mathrm{m}^{-1}$ and rise up to $20 \%$ with values greater than $4 \mathrm{dS} \mathrm{m}^{-1}$ within the first $150 \mathrm{~cm}$ soil depth. Yields were reduced by $13 \%$ in citrus and $30 \%$ in plums with conductivities less than $3 \mathrm{dS} \mathrm{m}^{-1}$ (Mass, 1986). In group 5 , fruit production was affected by the low soil effective depth.

\section{Relationships between soil characteristics and internal maturity indices}

The recommended internal maturity indices values to start the harvest of 'Williams' pears in the Upper Rio Negro Valley were: flesh firmness between 8.62 and 9.52 $\mathrm{kg} \mathrm{cm}{ }^{-2}$, total titratable acidity between 0.3 and $0.4 \mathrm{~g} \%$ malic acid, and soluble solids higher than $10 \%$ (Calvo et al., 2010). Flesh firmness and titratable acidity were the most affected indices by soil texture and chemical composition in groups 2 and 3, whereas titratable acidity and SS were affected in fruits obtained from plants with saline (group 4) and hydric stress (group 5), with consequent depreciation in fruit quality.

Fruits in group 2 presented an appropriate flesh firmness value according to the harvest date set for the region in both growing seasons (Table 6). However, fruits in group 3 in 2009 and in group 4 in 2010 should had been retained in the plants for a longer period due to flesh firmness values $>9.52 \mathrm{~kg} \mathrm{~cm}^{-2}$ at harvest time in order to reach an optimal maturity level for storage and 
commercialization. Flesh firmness depends on soil levels of $\mathrm{Ca}^{++}$and $\mathrm{K}^{+}$(Benítez et al., 2005; Sánchez, 2007). It has been shown that $\mathrm{Ca}$ interacts with other elements and plays a central role in cell functioning, a high $\mathrm{Ca}$ level in pear is associated with slower degradation of the cellular structure (Bangerth, 1974). Group 2 presented lower $\mathrm{Ca}$ concentrations in terms of \% calcium carbonate than group 3 and group 4 (Table 7), this could explain the lower flesh firmness values found in fruits from such group. Even though group 4 presented similar $\mathrm{K}^{+}$ content to group 2, group 4 contains $71 \%$ more calcium carbonate, then this condition could allowed the fruit to keep its firmness for a longer period. Also, group 3 presents $43 \%$ more $\mathrm{Ca}^{++}$than group 2 and a higher $\mathrm{K}^{+}$ concentration, it could explain the high firmness caused by synergism of both nutrients.

The highest flesh firmness was observed in group 5, related to soil physical characteristics: shallow, with $57 \%$ of sand and high percentage of coarse fragments. This increased firmness is associated with a greater elasticity of cell wall caused by dehydration. Fruits that contain less volume of water generate a higher concentration of soluble solids (Benítez et al., 2005).

Titratable acidity was higher in group 4 in 2009 (Table 6). Salt stress to which plants were subjected in this group creates defense mechanisms such as significantly reducing the osmotic potential of the fruit, increasing soluble solids concentration to prevent dehydration, and increasing levels of titratable acidity, organic acids and DM content (Musacchi et al. 2006). Soils that had more than $35 \%$ ESP showed an increase in the percentage of soluble solids, titratable acidity, and flesh firmness (Aruani et al., 2011). These results agree with Hudina and Štampar (2005), who noted that content of sugar and organic acids depends on plant genotype, environmental conditions and are influenced by irrigation system and soil nutrients availability. Hudina and Štampar (2002) shown that $\mathrm{P}$ and $\mathrm{K}$ foliar nutrition in pear "Williams" resulted in higher levels the SS and organic acids (malic, citric), and improved the quality and life of stored fruits. According to Lombardi et al. (2000) and Parra-Coronado et al. (2006), acidity is a heterogeneous parameter in fruits of the same age. In spring 2010, the cloudy and cool environmental conditions increased acidity of fruits in all soil groups compared to the previous growing season (Table 6).

The percentage of SS from groups 1 to 4 (11\%) was different from group $5(14.8 \%)$. This value is directly related to an accelerated process of maturation at the official harvest date, influenced by less retentive and warmer soil characteristics. During maturation, cementing substances (protopectins and pectin) that give fruit turgor are transformed into water-soluble pectic acids and other substances, producing the characteristic softening of ripe fruit (Parra-Coronado et al., 2006).

\section{CONCLUSION}

The results of this investigation showed that the selected set of edaphic variables (percentages sand, silt and clay, $\mathrm{pH}$, electrical conductivity, potassium, calcium carbonate, bulk density, $\mathrm{Na}$ adsorption ratio, and cation-exchange capacity allowed us to differentiate soil groups and to determine their influence on total yield, commercial size, and fruit internal maturity at harvest of pear trees 'Williams'. Deep, homogeneous soils with clay loam textures, good supply of potassium and low salt content are recommended to obtain good commercial yields in the Upper Rio Negro Valley. In addition, soil characteristics influenced flesh firmness and percentage of soluble solids of fruits.

\section{ACKNOWLEDGEMENTS}

To Laura Vitta and Juan Jose Iuorno from Kleppe S.A. Company for their assistance in the field work. This study was developed under Research Project PI 04/A099 "Relationship between soil quality indicators and yield in pome fruit trees in Upper Rio Negro Valley", funded by Universidad Nacional del Comahue in collaboration with Kleppe SA Company.

\section{LITERATURE CITED}

Ajeet, S., and P. Ramasare. 2009. Salt stress effects growth and cell wall bound enzymes in Arachis hypogaea L. seedlings. International Journal of Integrative Biology 7:117-123.

Altube, H.A., L.A. Santinoni, y H.J. Alem. 2007. Introducción a la fruticultura. p 3-38. In Sozzi, G.O. (ed.) Árboles frutales: Ecofisiología, cultivo y aprovechamiento. Editorial Facultad de Agronomía, Universidad Nacional de Buenos Aires, Buenos Aires, Argentina.

Apcarian, A., M.C. Echenique, M.C. Aruani, y P. Reeb. 2006. Efecto de capas endurecidas de suelos sobre el potencial productivo de viñedos, Alto Valle de Río Negro, Patagonia, Argentina. Agricultura Técnica (Chile) 66:70-79.

Aruani, M.C., N. Barnes, G. Striebeck, B. Osre, and Y. Machuca. 2011. Physical and physico-chemical properties of saline soils and effects on yield and quality of 'Williams' pear in the Upper Rio Negro Valley, Argentina. Acta Horticulturae 909:303-308.

Aruani, M.C., y S. Behmer. 2004. Efecto de la granulometría y la compactación del suelo sobre la distribución de raíces en manzano. Revista RIA de Investigaciones Agropecuarias (Argentina) 33(2):55-66.

Aruani, M.C., E. Sánchez, C. Dussi, y C. Arjona. 2001. Micronutrientes disponibles en suelos del Alto Valle de Río Negro, Argentina. Agro-Ciencia (Chile) 17(1):23-28.

Aruani, M.C., E.E. Sánchez, P. Reeb, y E. Aun. 2007. Variación de la concentración de nitratos en un suelo franco limoso del Alto Valle de Río Negro. Revista de la Facultad de Ciencias Agrarias 39(2):25-33.

Bangerth, F. 1974. Antagonism between calcium and other elements in the apple fruit. Acta Horticulturae 45:49-52.

Bengough, A.G., B.M. McKenzie, P.D. Hallettand, and T.A. Valentine. 2011. Root elongation, water stress, and mechanical impedance: a review of limiting stresses and beneficial root tip traits. Journal of Experimental Botany 62:59-68. 
Benítez, C., H. Castro, A. Ricca, y S. Vaudagna. 2005. Peras y manzanas: Factores que afectan la calidad de los frutos. 394 p. Ediciones INTA, Buenos Aires, Argentina.

Bramardi, S.J., P. Reeb, V. Tassile, y F. De Bernardin. 2006. Tablas de Raleo: Crecimiento de frutos de pepita en el Alto Valle de Río Negro y Neuquén. Área de Estadística. 24 p. Facultad de Ciencias Agrarias, Universidad Nacional del Comahue, Neuquén, Argentina.

Bronwyn, A.M., D.W. West, and L. Callinan. 1995. Long term effects of saline irrigation on the yield and growth of mature Williams pear trees. Irrigation Science 16:35-46.

Calvo, G., T. Gomila, N.E. Barnes, A.P. Candan, y J. Aragon. 2010. Manejo de poscosecha. p. 126-138. In Pera Williams. Manual para el productor y el empacador. Impreso por Erregé y asociados, Buenos Aires, Argentina.

CIL. 1991. Estudio para el Aprovechamiento Integral del Río Negro. Etapa II Informe Edafológico. 243 p. Consorcio Inconas Latinoconsult (CIL), Buenos Aires, Argentina.

Di Rienzo, J.A., F. Casanoves, M.G. Balzarini, L. Gonzalez, M. Tablada, y C.W. Robledo. 2011. InfoStat. Software estadístico. Facultad de Ciencias Agropecuarias, Universidad Nacional de Córdoba, Córdoba, Argentina. Available at http://www.infostat. com.ar (accessed June 2012).

Draghi, L., D. Jorajuría, C. Cerrisola, e L.M. Delgado. 2005. Resistência específica do dolo de um pomar frutícola relacionada ao manejo entrelinhas e intensidade de tráfego. Engenharia Agrícola 25:385-394

Dussi, M.C., G. Giardina, P. Reeb, and J. Gastiazoro. 2008. Thinning programs in pears cv. Williams. Acta Horticulturae 800:119-129.

Dussi, M.C., and D. Sugar. 2010. Fruit thinning and fruit size enhancement with 6-Benzyladenine. Acta Horticulturae 909:403407.

Echenique, M.C., A. Apcarian, P. Reeb, and M.C. Aruani. 2007. Growth-yield relationship of grapevine cultivars on soils with hardened layers, Alto Valle of the Río Negro, southern winegrowing region of Argentina. Agricultura Técnica (Chile) 67:261270.

Escofier, B., and J. Pagès. 1994. Multiple factor analysis (AFMULT package). Computational Statistics \& Data Analysis 18:121-140.

Fallahi, E., B. Fallahi, G.H. Neilsen, D. Neilsen, and F.J. Peryea. 2010. Effects of mineral nutrition on fruit quality and nutritional disorders in apples. Acta Horticulturae 868:49-60.

FAO. 2009. Guía para la descripción de suelos. $4^{\text {a }}$ ed. 99 p. FAO, Roma, Italia.

Gimenez, G., P. Reeb, M.C. Dussi, F. Elosegui, P. Siviero, S. Fantaguzi, et al. 2010. Optimizing benzyladenine application timing in Williams pear. Acta Horticulturae 884:265-272.

Grattan, S.R., and C.M. Grieve. 1998. Salinity-mineral nutrient relations in horticultural crops. Scientia Horticulture 78:127-157.

Hudina, M., and F. Štampar. 2005. The correlation of the pear (Pyrus communis L.) cv. Williams' yield quality to the foliar nutrition and water regime. Acta Agriculturae Slovenica 85(2):179-185.

Hudina, M., and F. Stampar. 2002. Effect of Phosphorus and potassium foliar fertilization on fruit quality of pears. Acta Horticulturae 594:487-493.

Husson, F., J. Josse, S. Le, and J. Mazet. 2010. FactoMineR: Multivariate exploratory data analysis and data mining with R. Version 1.14. Available at http://cran.r-project.org/web/packages/ FactoMineR/ (accessed January 2014).

Khayyat, M., E. Tafazoli, S. Eshghi, M. Rahemi, and S. Rajaee. 2007. Salinity. Supplementary calcium and potassium effects on fruit yield and quality of strawberry (Fragaria ananassa Duch.) American-Eurasian Journal of Agriculture and Environmental Science 2:539-544.

Liang, Y., M. Nikolic, Y. Peng, W. Chen, and Y. Jiang. 2005. Organic manure stimulates biological activity and barley growth in soil subject to secondary salinization. Soil Biology and Biochemistry 37:1185-1195.
Lombardi, S.R.B., D.M. Moraes, e D. Camelatto. 2000. Avaliação do crescimento e da maturação pós-colheita de pêras da cultivar Shinsseiki. Pesquisa Agropecuária Brasileira 35:2399-2405.

Mass, E.V. 1986. Salt tolerance in plants. Applied Agricultural Research 1:12-26.

Marcelle, R.D. 1995. Mineral nutrition and fruit quality. Acta Horticulturae 383:219-225

Merwin, I.A., and C.S. Warren. 1994. Orchard groundcover management impacts on apple tree growth and yield, and nutrient availability and uptake. Journal of the American Society for Horticultural Science 119:209-215.

Musacchi, S., M. Quartieri, and M. Tagliavini. 2006. Pear (Pyrus communis) and quince (Cydonia oblonga) roots exhibit different ability to prevent sodium and chloride uptake when irrigated with saline water. European Journal of Agronomy 24(4):268-275.

Noë, N., T. Eccher, D. Porro, and R. Stainer. 1997. Quality of golden delicious apples as affected by season and by nitrogen and potassium mineral nutrition. Acta Horticulturae 448:487-498

Parra-Coronado, A., J.E. Hernández, y J.H. Camacho-Tamayo. 2006. Estudio de algunas propiedades físicas y fisiológicas precosecha de la pera variedad Triunfo de Viena. Revista Brasileira de Fruticultura 28(1):55-59.

R Development Core Team. 2012. R: A language and environment for statistical computing. R Foundation for Statistical Computing, Vienna, Austria

Rhoades, J.D., A. Kandiah, and A.M. Mashali. 1992. The use of saline waters for crop production. 133 p. FAO, Rome, Italy.

Sánchez, E.E. 2007. Nutrición mineral y fertilización de frutales en hojas caducas. p. 397-431. In Sozzi G.O. (ed.) Árboles frutales: Ecofisiología, cultivo y aprovechamiento Editorial Facultad de Agronomía, Universidad Nacional de Buenos Aires, Buenos Aires, Argentina.

Sánchez, E.E.,A. Giayetto, L. Cichón, D. Fernández, M.C. Aruani, and M. Curetti. 2007. Cover crops influence soil properties and tree performance in an organic apple (Malus domestica Borkh.) orchard in northern Patagonia. Plant and Soil 292:193-203.

Sharples, R.O. 1980. The influence of orchard nutrition on the storage quality of apples and pears grown in the United Kingdom. Acta Horticulturae 92:17-28

Soil Survey Manual. 1995. Handbook nr 18. 336 p. United States Department of Agriculture Soil Conservation Service, Washington D.C., USA.

Soil Survey Staff. 2010. Keys to soil taxonomy. Agricultural Handbook 436. 365 p. $11^{\text {th }}$ ed. USDA Natural Resources Conservation Service, Washington, D.C., USA.

Stino, R.G., A.T. Mohesen, M.M. Yehia, and M.A. El-Wahab. 2011. Enhancing the productivity and fruit quality of le Conte pear via growth regulators, nutrients and amino acids. Journal of Horticultural Science and Ornamental Plants 3(1):65-74.

Talledo Yovera, J., y R.A. Pacheco. 1969. Estudio de factibilidad para el desarrollo de la región del Comahue. Vol. II Estudio de reconocimiento de Suelos del Alto Valle del Río Negro. 155 p. Sector Suelos, Consejo Federal de Inversiones (CFI), FAO, United Nations Development Programme (UNDP), Bahía Blanca, Buenos Aires, Argentina

Tejada, M., C. Garcia, J.L. Gonzalez, and M.T. Hernandez. 2006. Use of organic amendment as a strategy for saline soil remediation: influence on the physical, chemical and biological properties of soil. Soil Biology and Biochemistry 38:1413-1421.

Walkley, A., and I.A. Black. 1934. An examination of Degtjareff method for determining soil organic matter and a proposed modification of the chromic acid titration method. Soil Science 37:29-37. 